University of Nebraska - Lincoln

DigitalCommons@University of Nebraska - Lincoln

PreColumbian Textile Conference VIII /

Jornadas de Textiles PreColombinos VIII (2019)

Centre for Textile Research

$6-2020$

\title{
The pre-Columbian textile collection of the German Textile \\ Museum Krefeld
}

Katalin Nagy

Follow this and additional works at: https://digitalcommons.unl.edu/pctviii

Part of the Art and Materials Conservation Commons, Fiber, Textile, and Weaving Arts Commons, Indigenous Studies Commons, Latin American Languages and Societies Commons, Museum Studies Commons, and the Other History of Art, Architecture, and Archaeology Commons

This Article is brought to you for free and open access by the Centre for Textile Research at DigitalCommons@University of Nebraska - Lincoln. It has been accepted for inclusion in PreColumbian Textile Conference VIII / Jornadas de Textiles PreColombinos VIII (2019) by an authorized administrator of DigitalCommons@University of Nebraska - Lincoln. 


\title{
The pre-Columbian textile collection of the German Textile Museum Krefeld
}

\author{
Katalin Nagy ${ }^{1}$
}

\begin{abstract}
The German Textile Museum in Krefeld houses a considerable collection of pre-Columbian textiles. Most originate from graves in the narrow arid area of the Peruvian coast. The original aim was to build an assemblage with the pedagogical and methodological intention of presenting a broad range of very different textile techniques in the education for the future textile workers of the industry in said region. With this intention in mind samples were gathered, and soon a few samples turned into an impressive collection in which almost all established pre-Columbian cultures and periods of the area of the Central Andes are represented.

The Museum recently started a new research project within the South-American collection. The special aim of this project is a complete new restructuring of the collection, which means, first, the identification of all fragments as a part of a textile object and, second, the classification of the culture and the region they belonged to.
\end{abstract}

Keywords: Textile industry, Andean textiles, German Textile Museum, Krefeld, collection documentation .

\section{Resumen}

El Museo Textil Alemán en Krefeld alberga una no tan bien conocida pero considerable colección de tejidos precolombinos. Casi todos estos tejidos provienen de tumbas ubicadas en una estrecha e árida zona de la costa peruana. El objetivo inicial detrás de esta colección era el de construir un conjunto de piezas con la intención pedagógica y metodológica de disponer de un amplio abanico de muestras de muy diferentes técnicas textiles para la formación de las nuevas generaciones de trabajadores textiles de la región. La motivación original de aquellos que iniciaron la labor recopilatorio condujo a la construcción de una impresionante colección, en la que están representadas casi todas las culturas y períodos precolombinos establecidos del área de los Andes Centrales.

El Museo inició hace poco un nuevo proyecto de investigación en la colección de América del Sur. El objetivo específico de este proyecto es el de implementar una organización completamente nueva de toda la colección. Eso significa primero, la identificación de todos los fragmentos como parte de objetos textiles y, segundo, la clasificación según la cultura y la región a la que pertenecen. Objetivo de esta presentación es por un lado dar a conocer a un público mucho más amplio la existencia de esta colección de tejidos precolombinos, poniendo el foco de atención sobre algunas de sus piezas más reseñables.

Palabras claves: Industria textil, textiles andinos, Museo Textil Alemán, Krefeld, documentación de la colección

\section{Résumé}

Le musée allemand du textile de Krefeld héberge une collection méconnue, mais non négligeable de textiles précolombiens. Ceux-ci proviennent presque entièrement de tombes localisées dans la zone étroite et aride de la côte péruvienne. L'objectif initial de cette collection était de réunir un ensemble de pièces afin de, sur un plan pédagogique et méthodologique, présenter un large éventail de techniques textiles très variées pouvant servir à la formation des futurs employés

1. Katalin Nagy, Deutsches Textilmuseum, Krefeld (German Textile Museum, Krefeld); South American Collection, Project "Shed Light” (Projekt “Ans Licht”): katalin.nagy.berlin@gmail.com

DOI: 10.32873/unl.dc.zea.1214

Published in PreColumbian Textile Conference VIII / Jornadas de Textiles PreColombinos VIII, ed. Lena Bjerregaard and Ann Peters

(Lincoln, NE: Zea Books, 2020). https://digitalcommons.unl.edu/zeabook/ 
de l'industrie textile de la région. L'intention des collectionneurs qui ont commencé ce projet a abouti à la création d'une collection impressionnante dans laquelle la quasi-totalité des cultures et des époques précolombiennes établies de cette région des Andes centrales est représentée.

Le musée a récemment lancé un nouveau projet de recherche de la collection sud-américaine. Le but principal de ce projet est la réorganisation complète de la collection, ce qui signifie premièrement l'identification de tous les fragments liés aux textiles et deuxièmement, la classification de la culture et de la région auxquelles ils appartiennent. Cette présentation vise à rendre publique l'existence de cette collection de textiles précolombiens et de mettre en lumière certains de ces éléments les plus importants.

Mots-clés: Industrie textile, textiles andins, Musée Textile Allemand Krefeld, documentation des collections.

\section{Introduction}

The German Textile Museum in Krefeld houses an excellent collection of historical garments. This collection has over 30.000 objects from all parts of the world and from the Antique to the present time. The Peru-collection of Krefeld is not completely unknown. Many specialists for pre-Columbian textiles have at least heard, or already read about some objects, may be in an article or by studying its catalogue. A few of them already visited the museum's storage. Still, the collection in Krefeld, until this day, is not as well known as it should be.

The local financial institution, the Sparkasse Krefeld, has its own cultural fund. The current project "Shed Light" is sponsored by this fund. The project "Ans Licht" (in German), "Shed light" is still running. The aim of the project is to present the collection, not only to scientists and tourists, but also to the local population. The research conducted focuses on four groups in particular; they are going to be presented in an exhibition. These are the Peruvian textiles, the historical European garments, the East-Asian textiles, and the early-Islamic -collection. A digital catalogue will provide a summary of the collection. This paper will give you a first impression of the research done so far and its first results.

In the following I present the history of the museum, with an emphasis on the Peru-collection and some of its samples.

Krefeld itself is a part of the geographical and political Lower Rhine region, an economic entity with its own history. A larger part of its past was shaped by the textile industry. The production of textiles played a very significant role there in that almost every family was involved in some way or another. It provided an identity and a livelihood to a large percentage of the city population.
In the Middle of the $19^{\text {th }}$ Century Krefeld was an internationally renowned centre of textile production, especially for silk, but it was not the only one, since Lyon in France and Mulhouse in Alsace had similar importance. A response to this competition was the modernisation of the Royal School of Weavers. Besides the complete renovation of the building structure and modernising of the machinery, a library was added and a collection of textile samples was established. Such a collection should include samples from all historical periods and from all parts of the world. Although the collection was an archaeological, ethnological, and historical one, here, at the school, the objects were only considered as products of a technology, and should, first of all, serve to improve the technological knowledge and give an inspiration for design. This led to the purchase of the textile collection in 1880 .

This purchase was the foundation for the collection of the German Textile Museum. Its oldest part comes from the private collection of Jakob Krauth (1833 - 1890), a sculptor from Mannheim. In 1879 he owned 1500 textiles from Asia and Europe which he exhibited in Frankfurt. ${ }^{2}$

"It was possibly through this exhibition that the Prussian state representatives became aware of him. In the course of the negotiations, 3974 pieces were chosen for the Krefeld school, among them all kinds of textile qualities of various cultures and ages (...)."3 Jakob Krauth bought it in 1880 from the Prussian state and brought it directly to Krefeld where it was named "Königliche Gewebesammlung”, Royal Textile Collection. This collection was surely well known among other artists and collectors. In 1886 it was mentioned in a journal for applied arts, which was distributed in all of Germany. ${ }^{4}$ The author of the article was a scholar of cultural studies and the curator of the Museum of Applied Arts (Kunstgewerbemuseum) in Berlin ${ }^{5}$, Max Heiden. Max Heiden

2. Paetz gen. Schieck, 2013, 48

3. Paetz gen. Schieck, 2013, 48f, 59: notes 12-15

4. Max Heiden, 1886. Kunstgewerbeblatt. Periodical of the Associations for Applied Arts in Germany.

5. Kunstgewerbemuseum zu Berlin. The history of the textile collection and the activities of Jakob Krauth was intensively studied and presented by Annette Paetz gen. Schieck, 2013: 46-61. 
worked especially on garments and textile products. ${ }^{6}$ It is documented that the Museum of Applied Arts in Berlin acquired textiles from Jakob Krauth in $1880 .{ }^{7}$ Certainly, pieces from Berlin must have been part of the collection in Krefeld as the archive of the museum still stores the small old inventory labels of pieces from the collection of the Museum of Applied Arts in Berlin. This connection between Berlin and Krefeld had an important aspect especially for the founding of the pre-Columbian collection.

\section{The beginning of the collection of pre-Columbian textiles}

Taking a look at the background is important in order to trace movement of the textile objects, unearthed somewhere in Peru, to Europe, to Germany, and the change of their significance later in Krefeld. The Krefeld collection offers a view of a specific case of this process and cannot, therefore, be applied universally.

When I saw the collection for the first time, I saw a lot of rather small pieces and immediately recognized that they were fragments, mainly with a straight cut edge. I had earlier studied the textile collection of the Ethnological $\mathrm{Mu}$ seum of Berlin as well as a few other collections in Germany. I assumed at first that most of those fragments came from Berlin. (Fig. 2). However, more study of the documents has brought me to a different conclusion. I now think that some of the pieces became a part of the collection in a different way.

In the German Textile Museum the question of provenience is considered with privilege. The period after the Second World War is well documented. But in the case of the whole collection including the pre-Columbian textiles, which entered the collection partly before the Second World War, the study of the acquisition is difficult as the documentation was completely destroyed. The Project Shed Light gave the possibility to examine every piece with its still existent file cards and at least for some of them the provenience can be cleared.
The acquisition of the objects began towards the end of the $19^{\text {th }}$ century and the process was documented. ${ }^{8}$ Unfortunately, the school building where all the documents were stored was destroyed by bombs during the Second World War. ${ }^{9}$ Some of the documents that were thought to be lost, actually were not. Clarifying this way, it was possible to recover some pre-Columbian pieces from the collection of Reiss and Stübel that entered the collection in Krefeld. Beside this small group of fragments, the vast majority of the pieces in Krefeld have no archaeological documentation.

The decades of the historical process of the great industrialization were also very important in the history of preColumbian Archaeology. The geologist Wilhelm Reiss (1838 - 1908) and the mineralogist Alphons Stübel (1835 - 1904) went to South America in $1868 .^{10}$ Their aim was to study volcanology and mineralogy, but as a common practice for scientists on journey at that time they also conducted archaeological excavations. Wilhelm Reiss and Alphons Stübel excavated between December of 1874 and March of 1875 the necropolis of Ancón at the Peruvian Coast. The documentation and creation of prints by Reiss and Stübel regarding the excavated objects were subsequently put into three volumes and published with the title "The Necropolis of Ancon in Peru". ${ }^{11}$ Exactly at that time, in 1886, the "Königliches Museum für Völkerkunde" (Royal Museum of Ethnology) in Berlin was inaugurated. The excavated artefacts from Ancón are now stored in the Ethnological Museum in Berlin, Germany. Many of the archaeological objects are textile pieces. The first pre-Columbian pieces entered the textile collection in Krefeld probably shortly after the foundation of the collection. Fifteen small fragments were donated ${ }^{12}$ that belonged to the objects excavated by Reiss and Stübel at the necropolis of Ancón. The time and circumstance of their entering is still unknown, but they were registered as one group, and received the number $55 .{ }^{13}$ The specification of the archaeological site must have been made by Reiss and Stübel themselves: "Südamerika, Peru, Chimu, Totenfeld von Ancon”. Also, the Grassi-Museum in Leipzig (Leipsic, old) received a part of the Reiss-and-Stübel-Collection in $1887 .{ }^{14}$

6. Max Heiden, 1904. Some other historical evidences show the connection between these two collections. Further see: Paetz gen. Schieck, 2013, 59f, notes 21-22

7. Paetz gen. Schieck, 2013, 50 and 59, note 21

8. Paetz gen. Schieck, 2013, 48

9. Paetz gen. Schieck, 2013, 49

10. Fischer, 1992, 259

11. The Necropolis of Ancon in Peru. Published by A. Asher, Berlin 1880-1887

12. "Provenienz: Dr. Reiss and Dr. Stübel, Berlin, Geschenk" (English: donation)

13. „A.N. 55”, in German „Alte Nummer”. English: old number 55. See every object card from the inventory number 10440 till 10457. The object cards with the numbers 10453, -54 and -55 are missing today. All pieces have a measurement of some centimetres. and were very probably cut off for the donation.

14. Fischer, 1992, 260 
As no information exists from the beginning of the preColumbian textile collection from Krefeld, the next question was, if the collectors in Krefeld had any contact to the Museum in Berlin. The contact between the Krefeld collection and both scientists is unclear until this day. I presume that the information about the arrival of pre-Columbian textiles to Europe and to Berlin, as a part of a pre-Columbian collection, had reached the elite of Krefeld. This historical frame is key to understanding the origin of this exceptional textile collection, including the Peru collection. Future research can lead to more knowledge about the early contacts between the scholars and collectors. Today, this group of textile fragments from the excavations of Reiss and Stübel in Ancón is part of the Krefeld collection. ${ }^{15}$ The question of provenience follows every new exposition of the Museum in Krefeld. Until now these pieces from Ancón are unique among the preColumbian textiles because their provenience was directly named by the archaeologist.

The Krefeld collection had such a high status and was considered so valuable that it was moved to a secure place during the Second World War. The documents, however, were left behind at the school. Unfortunately, the school building was destroyed in a 1943 bombing. This is why there is no information about many of the collectors or possible origin of the textiles.

In 1949, after the war ended, a new institution, called the "Centre for the Restauration of Historical Textiles and Garments”, in German „Zentrale Forschungstelle für Restaurierung historischer Gewebe“, was established. It was tasked with the preservation of all damaged textile goods. It was led by the new director of the Textile collection, Dr. Renate Jaques. Renate Jaques, an art historian, was the first person who took care of the entire collection. She was well known amongst the textile institutions in Krefeld and kept close connection to the Textile Engineer School.

\section{The years of the extension}

Shortly after the Second World War the most important question that many European museums and collections asked themselves, was, what was lost and what could still be saved for expositions. Those years seem to have been an era when the curators of textile collections tried to intensify dialogues among themselves. In 1954 Renate Jaques belonged to a small international group of scholars who gathered in Lyon. They established the scientific association of the CIETA, the "International Research Centre for ancient textiles", which is still active in research of archaeological and historical textiles.

Some pre-Columbian objects, mainly fragments, were acquired, when the German-Peruvian collector and textile merchant Guillermo Schmidt-Pizarro brought them to Krefeld. His name appears in several European museums within their pre-Columbian textile collections ${ }^{16}$ as he offered objects with pre-Columbian origin to a number of European museums. The first time he came to Krefeld and presented pre-Columbian garments was shortly after the end of the Second World War. Later he presented more pre-Columbian garments and a number of smaller fragments. Guillermo Schmidt-Pizarro must have been aware that in a city with such a long textile tradition, the pieces with the most fascinating techniques would be highly valued and very welcomed. Some pieces were registered with a cultural assignment, it happened very probably on the suggestion of Schmidt-Pizarro himself. Regarding the pre-Columbian collection it is not possible to clear on which of the archaeological sites the samples were found.

He visited Krefeld between 1953 and 1960 a few times, the date of the first visit is indicated $1953^{17}$ and also the last one, 1962. The investigation of the documents has not been finished yet, but they span a period of 10 years. Presumably he brought the last piece on the $23^{\text {rd }}$ of May 1962 and the date of his denial was written down on the same document: “...Tod des Anbietenden am 20.1. 1964”. This was the last time he was mentioned. Actually, the source of this information is unknown.

This array of textiles was last presented publicly in an exhibition in 1959. Photographs of some of the objects were published, but later the collection sank into oblivion. The first catalogue from 1959 consisted of some printed pages and was no more than a list of the objects. Over the years the city-collection offered some objects to other museums for expositions. The most active cooperation was with the Ethnological Museum of the city of Cologne. The moment textiles were exhibited, the experience of the specialists from the Krefeld-collection also

15. Wilhelm Reiss was born in Mannheim where Jakob Krauth was also living before and after the three years of intensively phase of founding of the textile collection in Krefeld (Paetz gen. Schieck, 2013, 6o, note 22).

16. The British Museum offers a short information to Guillermo R. Schmidt-Pizarro, though he belonged to its collectors. He was born ca. 1881 and has diseased ca. 196o. See: Bibliographical details of Guillermo R. Schmidt-Pizarro: "Collector of predominantly Peruvian textiles, examples of which can now be found in numerous museums, including the British Museum.” (c) 2019 Trustees of the British Museum. (https://research.britishmuseum.org/research/search_the_collection_database/term_details.aspx?bioid=35776) 26.11.2019.

17. Registration on the object card of Inv. Nr. 04566. 


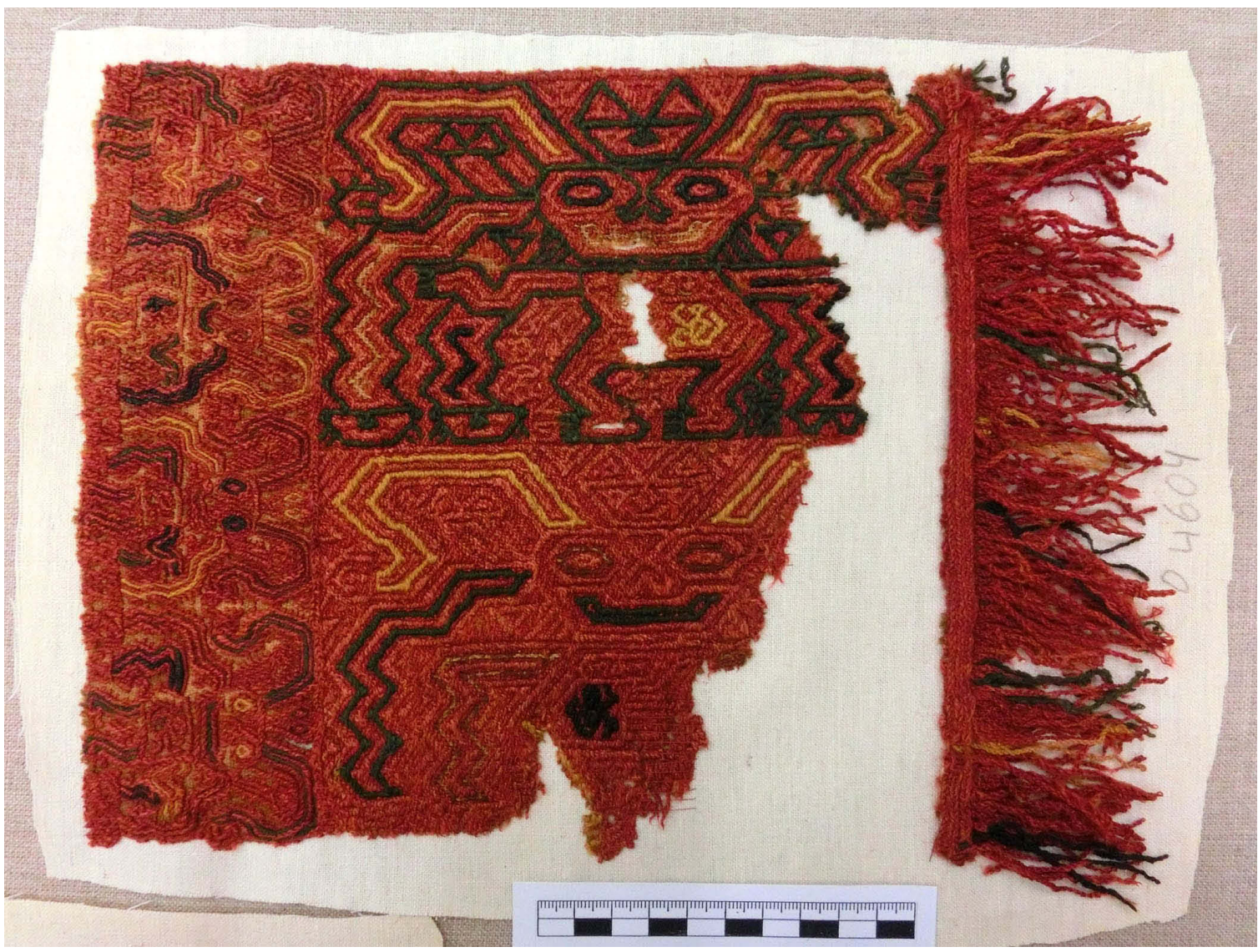

Figure 1. Late Paracas fragment ( $400-200 \mathrm{BC}$ ). Cotton plain weave, with embroidery in dyed camelid hair, $30 \mathrm{x} 21,5 \mathrm{~cm}$ with fringes, the fringes are ca. 6,5 cm (DTM Inv. Nr. 04604) (Katalin Nagy, DTM: Deutsches Textilmuseum, Krefeld) Except the two photos of the object DTM Inv. Nr. 12299 all photos were made by the author of this article. They are published here with the permission of the DTM (Deutsches Textilmuseum, Krefeld).

became important. Today the Peruvian collection itself counts about 800 pieces. ${ }^{18}$

Renate Jaques remained in Krefeld at her position until 1973 when she retired, and the city took over her institution. Since then, the collection has changed its name and location several times. It was eventually removed from the school in the late 1970s and stored in a new and modern building, where the collection received the status of museum sponsored by the city. The museum has been located in Krefeld-Linn since 1980 and it is called Deutsches Textilmuseum. The textile collection still constitutes the core of the museum. The development of cultural and social sciences led to the recognition by the elite of Krefeld that the textile objects were more than mere examples of textile techniques so the interest in their cultural and historical background began to grow and the next CIETA meeting in
1980 took place here in Krefeld.

\section{Some pieces from the pre-Columbian textile collection}

The collection includes pieces representing different techniques and designs and some selected pieces are presented here in chronological order.

\section{Early Intermediate Period (ca. 600 B.C. - 600 A.D.)}

Two pieces, one from the Paracas and another from the Nasca culture (Fig. 1 and Fig. 2).

The piece from the Late Paracas culture (DTM Inv. Nr. 04604) is a fragment from the border of a decorated shirt. Corresponding to other published examples it originates

18. According to the list of the inventory numbers 822 pieces came from Peru and 11 from Bolivia. The real number of objects can slightly differ, because pieces made of different parts and with different techniques received sometimes more than one number. Depending on the institutionally interests of the museum on textile techniques it seems that in the past not the object but the technique was registered. An example is a small bag, a chuspa, with the inventory number 11088-89-91. It will be presented later on in this paper, Figure 2. 


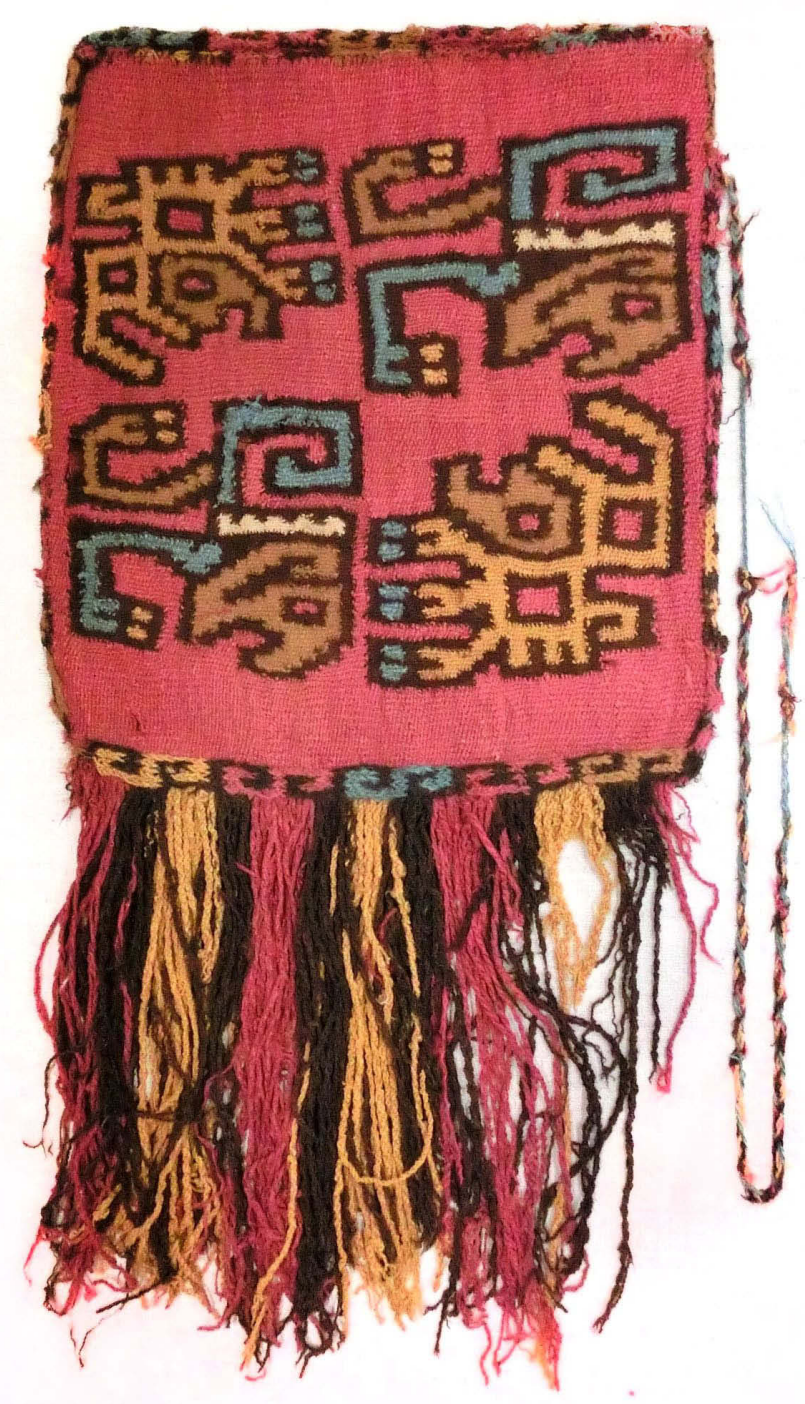

Figure 2. Small bag, chuspa, from the Late Nasca culture (500 700 AD). Dyed camelid hair, discontinuous warp and weft pattern, $22,5 \times 20,5 \mathrm{~cm}$. with fringes is ca. $41 \mathrm{~cm}$ long, the braided hanger is $50 \mathrm{~cm}$ (DTM Inv. Nr. 11088-89-90)

from the Paracas necropolis (400 - 200 B.C.). The decoration is embroidery on cotton plain weave with dyed $\mathrm{S} 2 \mathrm{Z}$ plied camelid hair, in the colours red, pink, yellow, black and dark green. The embroidery is an example of the linear style. The main motif is a combination of frontal anthropomorph and zoomorphic figures, in the stomach area of an anthropomorph figure there is a small zoomorphic figure. The outlines of the repeated motive were changed. The plied fringe is a common decoration on shirts. ${ }^{19}$
The next piece from the Nasca culture is a small bag, chuspa, (DTM Inv. Nr. 11088-89-90) with fringes and with its partly fixed braided hanger. The three inventory numbers for this object are a special phenomenon in the collection with its profile of textile techniques. Every part of the bag was made with different techniques, it means that every used technique obtains a number. The decoration of the bag was made with discontinuous warp and weft. The material used are dyed yarns of camelid hair. The fringes are multiple plied camelid hair. Two pairs of zoomorphic figures positioned diagonally to each other, are the decoration of the chuspa.

\section{Middle Horizon (ca. 600 - ca. 1000 A.D.)}

Several object groups are known to represent the Middle Horizon. I have chosen three objects: a Huari tapestry shirt, a tie-dyed-Huari-Nasca tunic and a feather-shirt. The Huari tapestry shirt (Fig. 3 and Fig. 4) is a complete piece. ${ }^{20}$ It is a tapestry on cotton warp with dyed camelid hair weft. After Susan E. Bergh the main motives presented are "camelid -or deer-headed staff-bearing creature in profile”. She mentions two related examples of Huari tunics from other collections decorated with similar main motives. ${ }^{21}$

\section{Nasca-Huari tie-dyed tunic}

A tie-dyed tunic with discontinuous warp and weft was described by Ann P. Rowe in the, already mentioned, Wari-Catalogue. She presented this tunic from the collection of the Textile Museum in Washington, and it is very similar in design to the example in Krefeld. It is said to have been found near Palpa in the Nasca-Drainage.

The Krefeld example is probably not complete, it measures $94 \mathrm{~cm}$ by $114 \mathrm{~cm}$. (Fig. 5) This example consists of small squares. But other tie-dyed tunics were made of stepped blocks or L-shaped pieces or a kind of hook. Further we read: "The diagonal rows of small diamonds in each unit combine with those of neighbouring units to form larger diamonds, and the colours repeat along diagonal axes. The colour units typically rotate from one diagonal row to another, adding kaleidoscopic variety." 22 This type of dye practice and construction is also presented on a smaller fragment in the Krefeld collection (Fig. 6). An enlarged photo of this fragment shows how the squares are placed (Fig. 7). To quote

19. More related examples are presented and detailed as described by Ann H. Peters, see Peters, 2014, 129ff

20. The first time it was presented was in 1971 on the occasion of an exposition of the Gewebesammlung Krefeld (Textile Collection Krefeld) and published in the catalogue "Kostüme Trachten Schmuck aus aller Herren Länder"(1971, Tafel 12, Kat. 81.). This object was last presented in the WARI - exposition in the Cleveland Museum of Art, and published in the catalogue, S. E. Bergh, 2012, 167, Figure 153.

21. S. E. Bergh, 2012, 167

22. A. P. Rowe, 2012, 196, Fig. 185. In: S. E. Bergh, 2012 

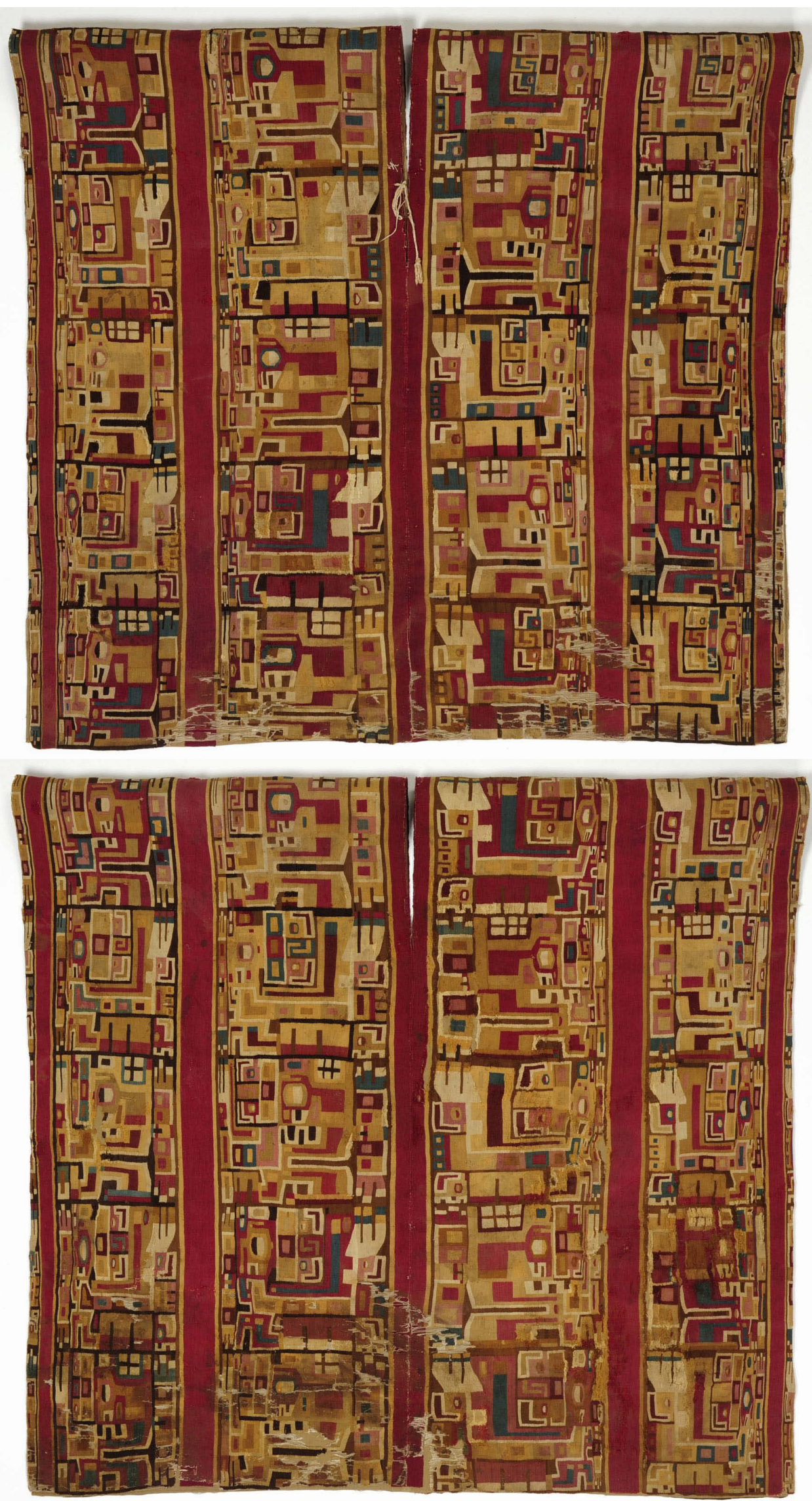

Figure 3. Shirt, uncu, from the Huari Culture (8 - 10 century AD). Dyed camelid hair weft on cotton warp, tapestry weave, $103,5 \mathrm{~cm} \times 108,5 \mathrm{~cm}$. (DTM Inv. Nr. 12299)

Figure 4. Backside of the same Huari shirt (DTM Inv. Nr. 12299) 


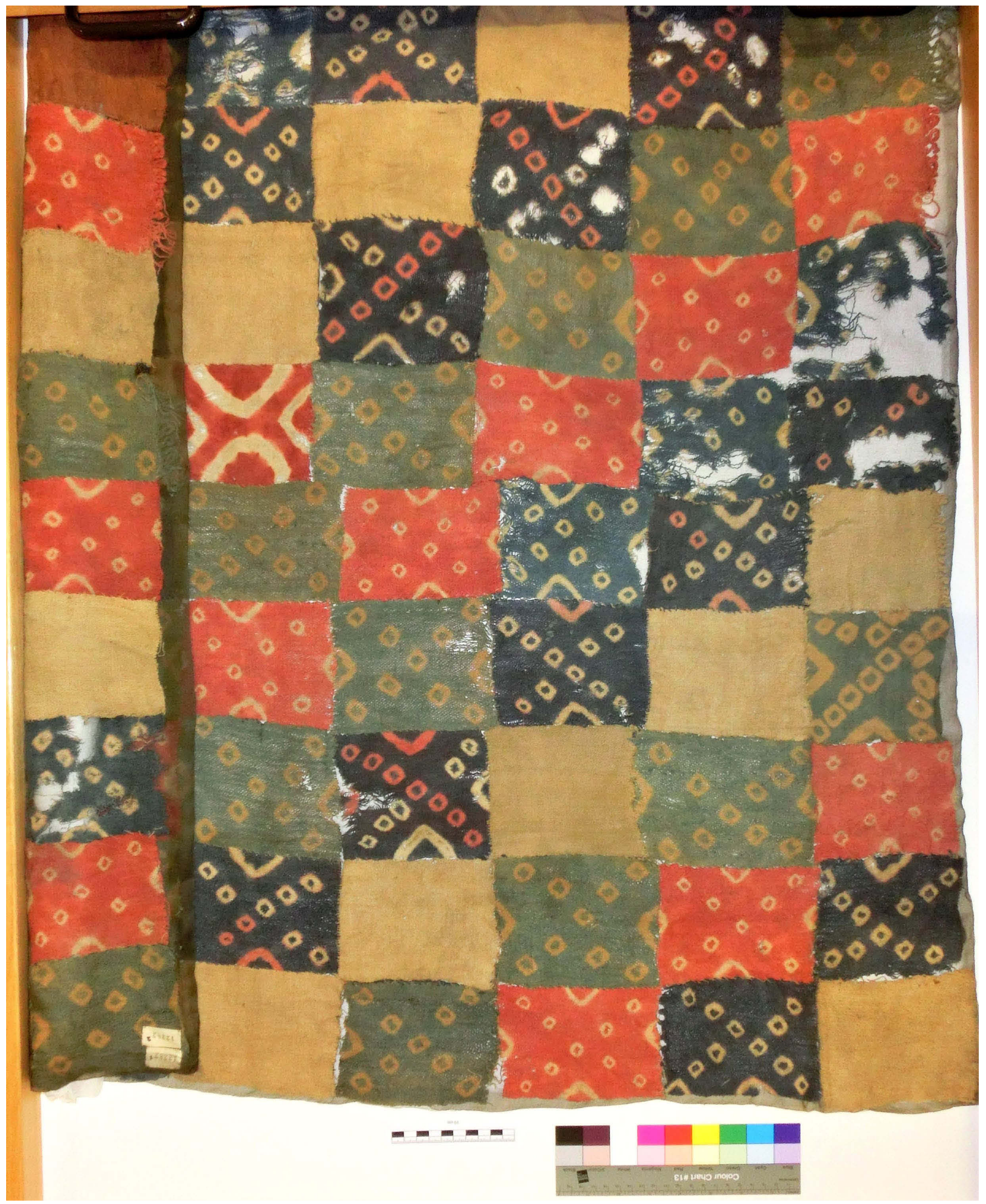

Figure 5. Nasca-Huari tie-dyed shirt. Camelid hair warp and weft, tie-dye and discontinuous weaving, 94 X $114 \mathrm{~cm}$ (DTM Inv. Nr. 12282) 


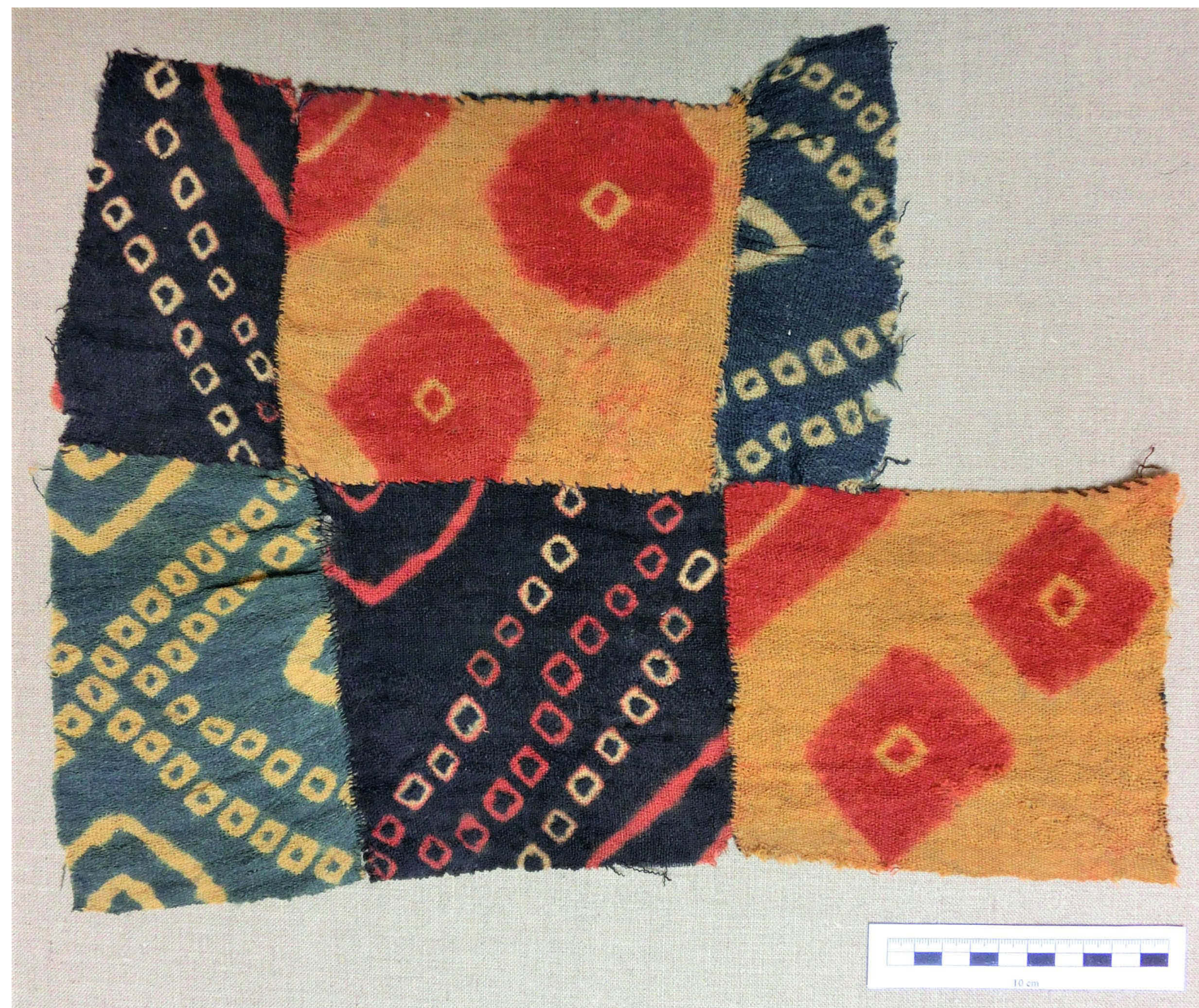

Figure 6. Fragment of a Nasca-Huari tie-dyed garment. Camelid hair warp and weft, tie-dye and discontinuous weaving, $41 \mathrm{x} 30 \mathrm{~cm}$ (DTM Inv. Nr. 11055)

Figure 7. Enlarged photo shoot of the Nasca-Huari fragment (DTM Inv. Nr. 11055)

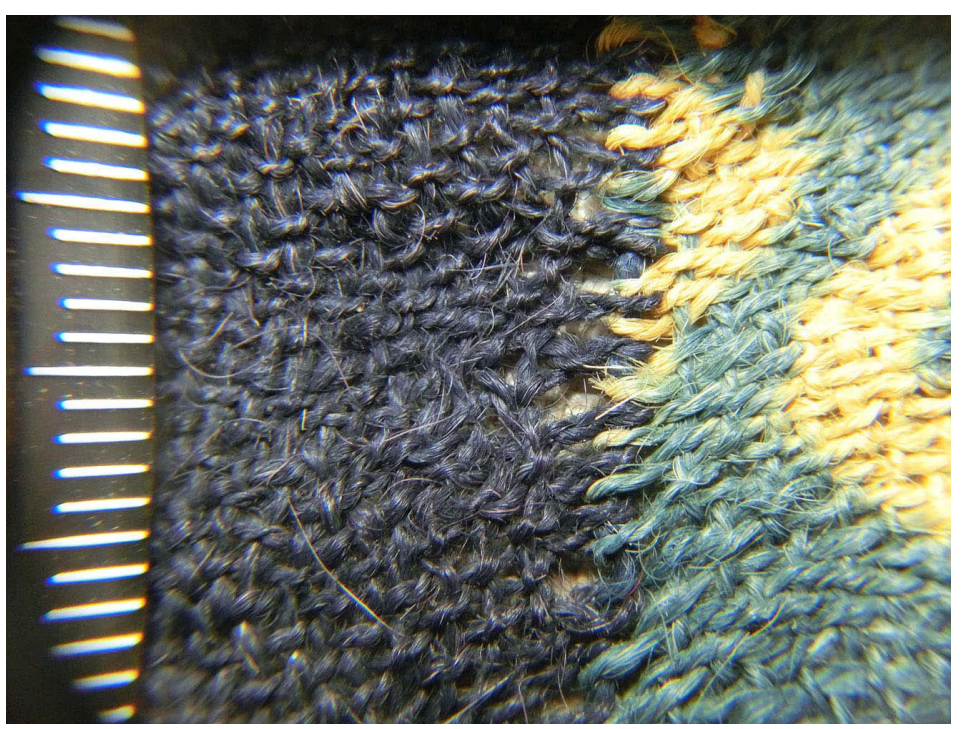


Ann P. Rowe: "Tie-dyed tunics are a coherent group technically and stylistically, and can be (...) described as Wari in style." (...) "The weaving method results in cloth in which both the warp and the weft are discontinuous, which simply means that no yarn runs continuously from top to bottom or from side to side." But we also read: "Not all discontinuous-warp-and-weft tie-dyed textiles are Wari either." The most recent excavations point on the possible existence of a South-Nasca style.

Multiple sketches and images show the attention paid to the documentation of the techniques. But this kind of interest in the complicated textile techniques led to a rather unusual composition in the collection. What is striking about the collection is that it does not include the important quipu and only two feather objects. We know that the quipus played an important role in the pre-Hispanic time. However, they were made of simple knots on a twined yarn, but it was seen as a technique not to pay much attention and interest to. I think this is the same reason that the collection includes only very few garments from the Inca Period, as tapestry, a relatively simple weaving technique, was used for the imperial uncus. Back then there was no reason, to collect any more items from that time period. In the 1950 s the knowledge about the textiles from the Inca Period was very limited, not only in Krefeld, but in Europe. The broad range of textile techniques used during the Inca Period was not present. Nevertheless, as other information is missing it is still possible that some other factors influenced the process of the collecting. The project "Shed light" will hopefully answer this question too.

\section{Feathers}

In the collection, there are only two feather objects and, in a certain way, they both have their peculiarities. A narrow feather-band belonged to the very early collection from before the war; its origin is unknown. The band has a simple but very stable narrow base woven or braided from thick cotton threads. Feathers in blue, red, and yellow were attached with stiches to its surface. The purpose of the band is unknown but it is possible that it served as a decorative element on a headdress.

Only one fragment of a feather-shirt, already heavily damaged, was bought in the 6os at an art auction. (Fig. 8) This purchase demonstrates the intention to make the collection more complex and it shows how the consideration of the value of the collection was changing at that time. The feathershirt is in rather bad condition. ${ }^{23}$ When I began to carefully examine the details of the feather textile, it soon became possible to make out feathers in many different colours and to reconstruct the original design. (Fig. 9) This closer examination helped to realise that other feather shirts, with similar design, exist and have already been published. ${ }^{24}$

\section{Late Intermediate Period (1000 - 1470 A.D.)}

\section{Chancay veils (gauze weave and knotted and looped nettings)}

Very sophisticated and outstanding techniques of different groups of the Late Intermediate Period, such as the Chancay textiles, are represented with more samples. The Chancay gauze weaves from the "Late Intermediate Period" is a truly fascinating collection and is the biggest object group among the pre-Columbian textiles in Krefeld. These garments, were maybe made for women as headgear and were very special due to their light weight and the fascinating techniques. We shall not forget, that the aim of the creation of this collection was to teach, to present more and more different, difficult, or complex techniques.

All pieces are finely made and many of them still have all four selvedges intact. They have a square shape, and are each sewed together from two panels - each with four selvedges. A dark blue specimen is presented here (Fig. 10). It was made from dark blue cotton yarns and the design was created through the crossings of the warps (gauze weave).

Other Chancay veils are made by knotting or looping a net-like ground that had stylized figures of animals embroidered on. It is possible that the pieces were sewn together to make even bigger objects. The biggest veil textile in the Krefeld Museum was composed from four complete square veils, all of them made from two panels. Two of these square veils are complete; there is a part missing from the third one, and the fourth only exists as a very small fragment. The item is $174 \mathrm{~cm}$ long and $148 \mathrm{~cm}$ wide. The four squares were originally nearly the same size. Every panel was made individually and each had its own design. Moreover, each square was sewn together from two seemingly identical parts. The stiches are hardly recognisable because the motives were perfectly fitted. ${ }^{25}$

Some documents show the effort made by Renate Jaques to deepen the knowledge about the cultural background and

23. The fragment of the museum is only one side of a whole shirt. It seems that this part has been laying on a board and the feathers have been damaged after a while.

24. I have found two other feather shirts with similar design: one in the book about pre-Columbian feather works (Heidi King, 2012, 136, Nr. 9.) and another one presented by Jose Alfredo Campos, 2015, 486: restauration and reconstruction of a strongly damaged feather tabard

25. DTM Inv. Nr. $12876,148 \times 174 \mathrm{~cm}$. 


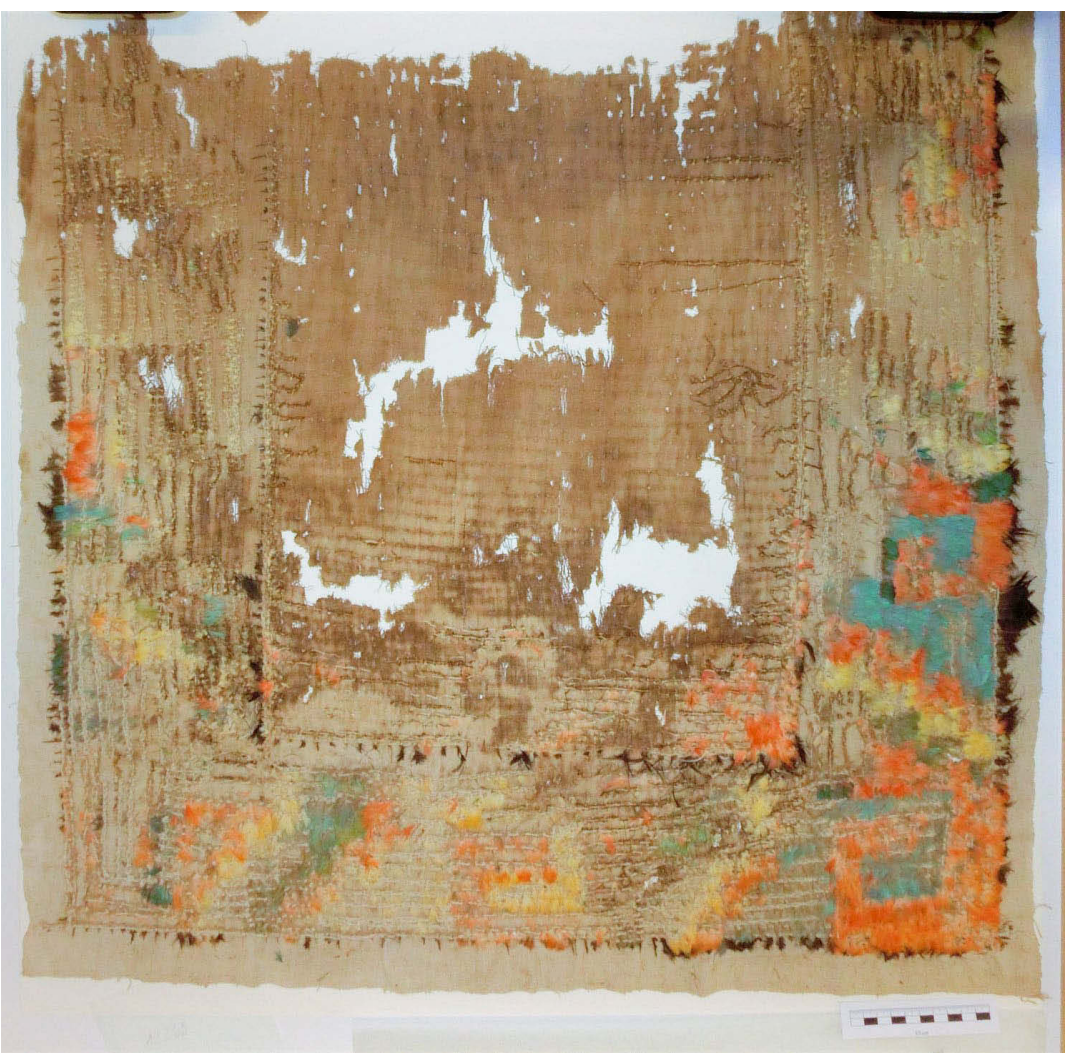

Figure 8. Feather tabard. Cotton plain weave, decorated with feathers of birds from the Amazonian rain forest, $74 \times 100 \mathrm{~cm}$ (DTM Inv. Nr. 12263)

Figure 9. Reconstruction of the design of the feather tabard (DTM Inv. Nr. 12263)

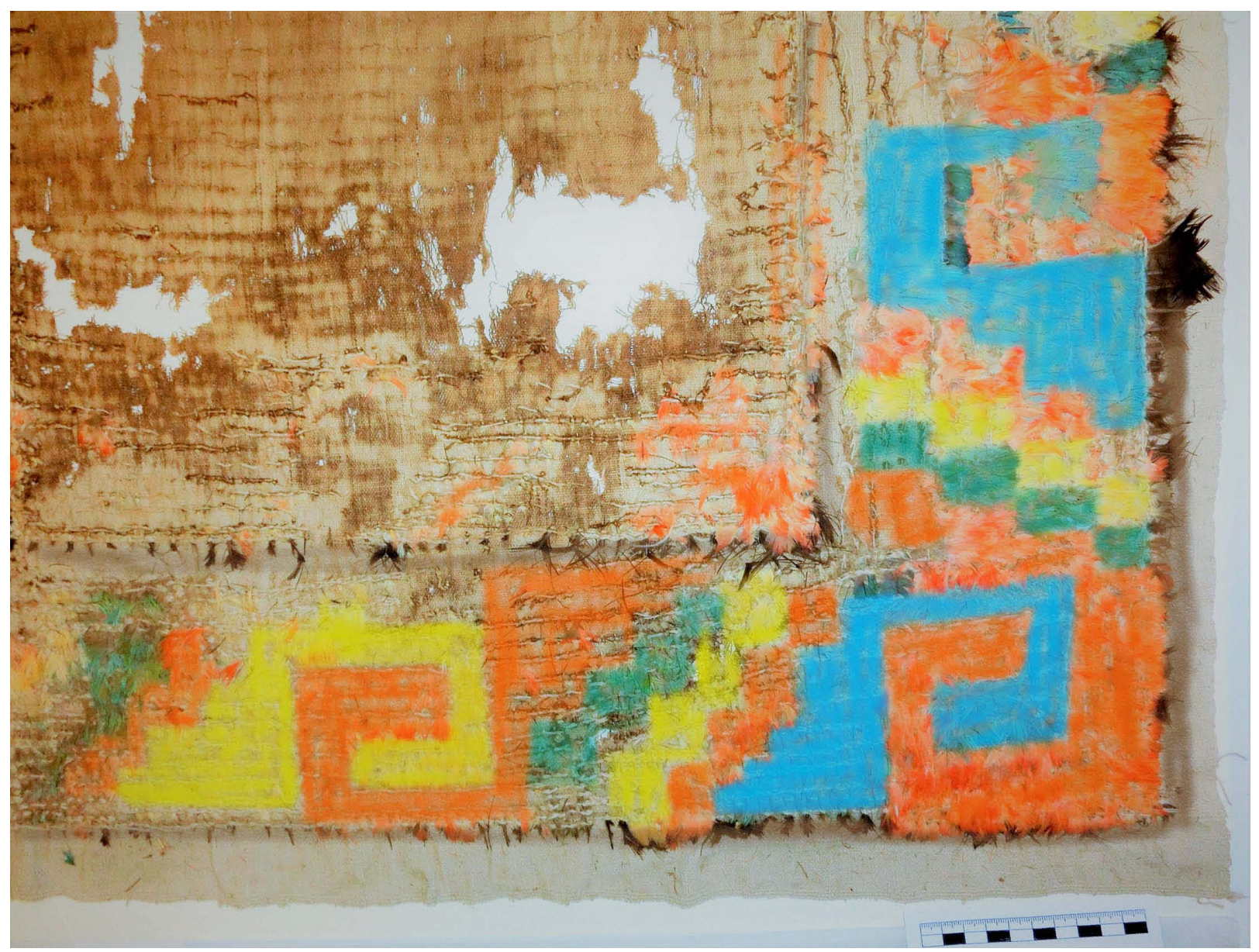




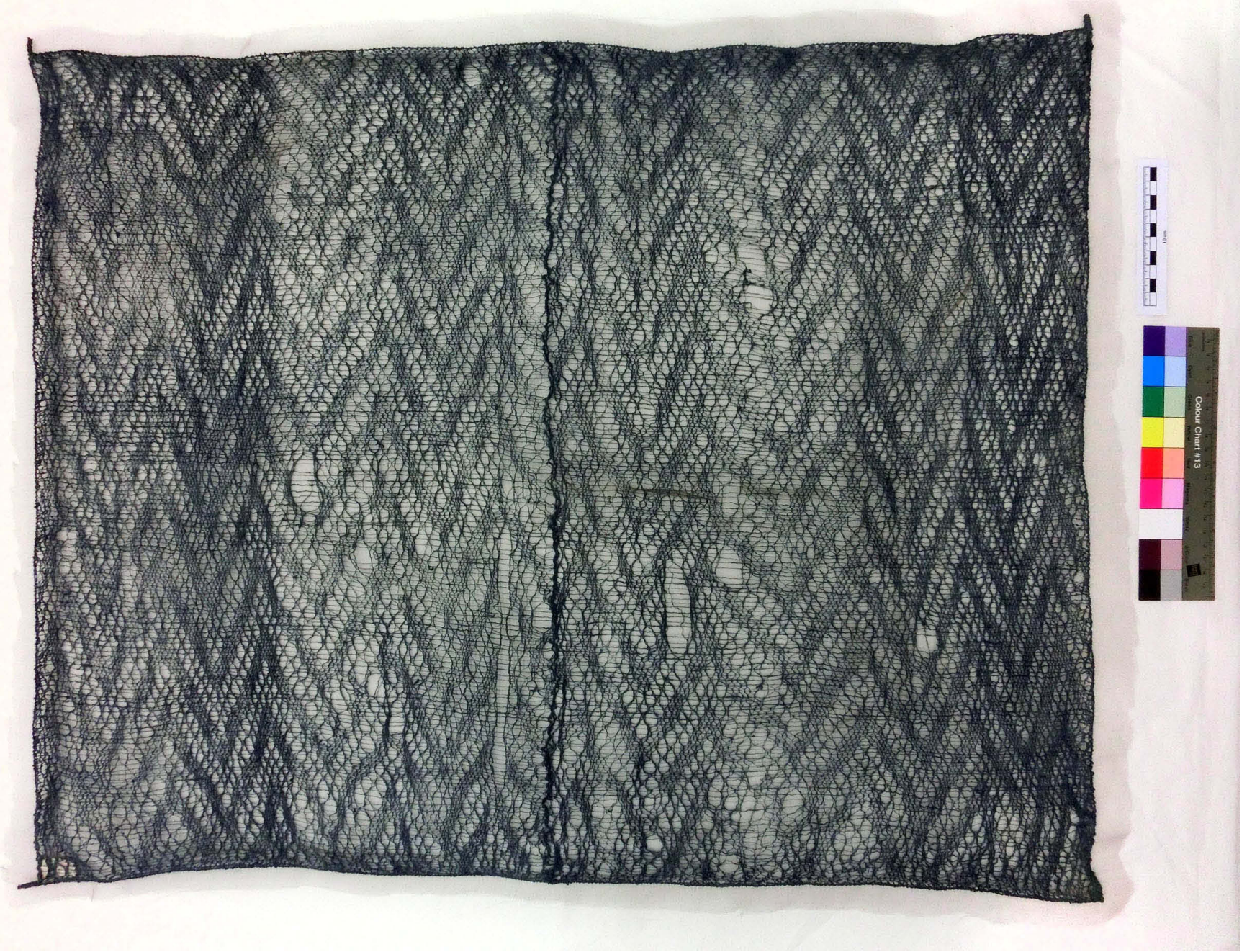

Figure 10. Chancay gauze weave with a chevron motif. Dark blue dyed cotton, 66,5 x 83 cm (DTM Inv. Nr. 12809)

to create a new catalogue. Hans-Dietrich Disselhoff, at that time director of the Völkerkunde Museum Berlin (today Ethnologisches Museum Berlin) was invited to Krefeld. He was asked for his scientific consultation and expertise about all pieces of the Peruvian textile collection. In June 1964, he spent a few days studying the pieces. Still in the first half of the 6os, perhaps on the advice of professor Disselhoff, Renate Jaques, the director of the collection, travelled to Peru twice. Her colleague from the textile collection, the textile engineer Miss Wencken, who was also responsible for the study and the identification of the textile techniques, accompanied her. They were very interested in the Chancay-veils and studied all the many veils in the Amano-collection in Lima. They compared eighteen pieces and created different groups based on the techniques used. In 1968, the results were presented at the 38th International Conference of the Americanists in Stuttgart, Germany. This article did not really create an echo, perhaps because it was written in German and I have not come across an English translation yet. ${ }^{26}$

\section{The Colonial Era (1530 - 1830)}

Some textiles in the collection belong to the Colonial era and some are ethnological. The next piece was definitely made in the Colonial Period. This intact woman's shawl is an example of the highland-style - warp-faced and warp patterned (Fig. 11). It is made from camelid hair in different colours, natural and dyed, with silver yarn added. This lliclla looks similar to many others made for rituals. ${ }^{27} \mathrm{Al}-$ though metal threads were already used in the $16^{\text {th }}$ century, 


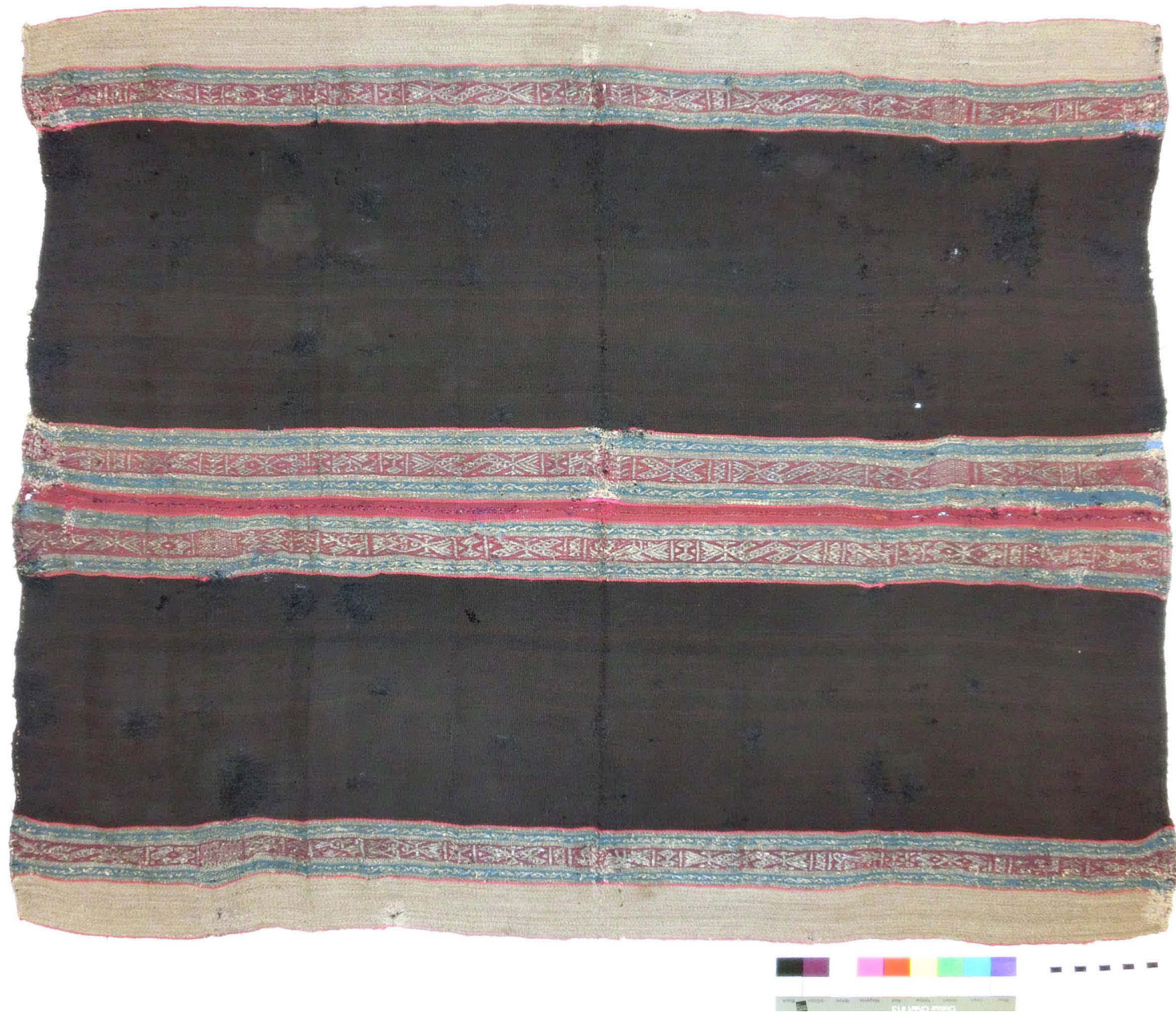

Figure 11. Lliclla, female shawl, with decorating warp pattern stripes with silver thread, probably $18^{\text {th }}$ Century. $96 \mathrm{x} 78 \mathrm{~cm}$ (DTM Inv. Nr. 12219)

a detail in the decoration, an anthropomorph motive points to it having been made in the $18^{\text {th }}$ century ${ }^{28}$. In the $16^{\text {th }}$ century gold and silver were already being shipped to Spain and metal threads from Europe were imported, where they were broadly used since about the $12^{\text {th }}$ century. ${ }^{29}$ "Metallic yarns were introduced into the weaving tradition of the Andes in the sixteenth century, after Spanish administrators and church officials began commissioning from native weavers tapestries derived from European models." ${ }^{30}$
"But documentary evidence suggests that it could also have been done in Peru, by artisans of varied ethnicities. For example, in Cusco in 1686, the goldsmith (tirador de oro y plata) Blas de Aguirre, likely a creole or mestizo, was contracted to work in a home over the course of four years. Part of his responsibility was to 'pull gold and silver into the state that it can be woven in silk or on thread." 31

What is special about this piece are the metal threads used for the traditional motifs on the broad warp pattern

28. The main motif of this lliclla, the "inkarrí" was appeared after 1780 .

29. Phipps, 2010, 9

30. Phipps, 2010, 4

31. In Spanish: "en hacer tirar oro y plata hasta poner en estado de que se hile en seda o en hilo." Stanfield-Mazzi, 2015,91 and note 43. 


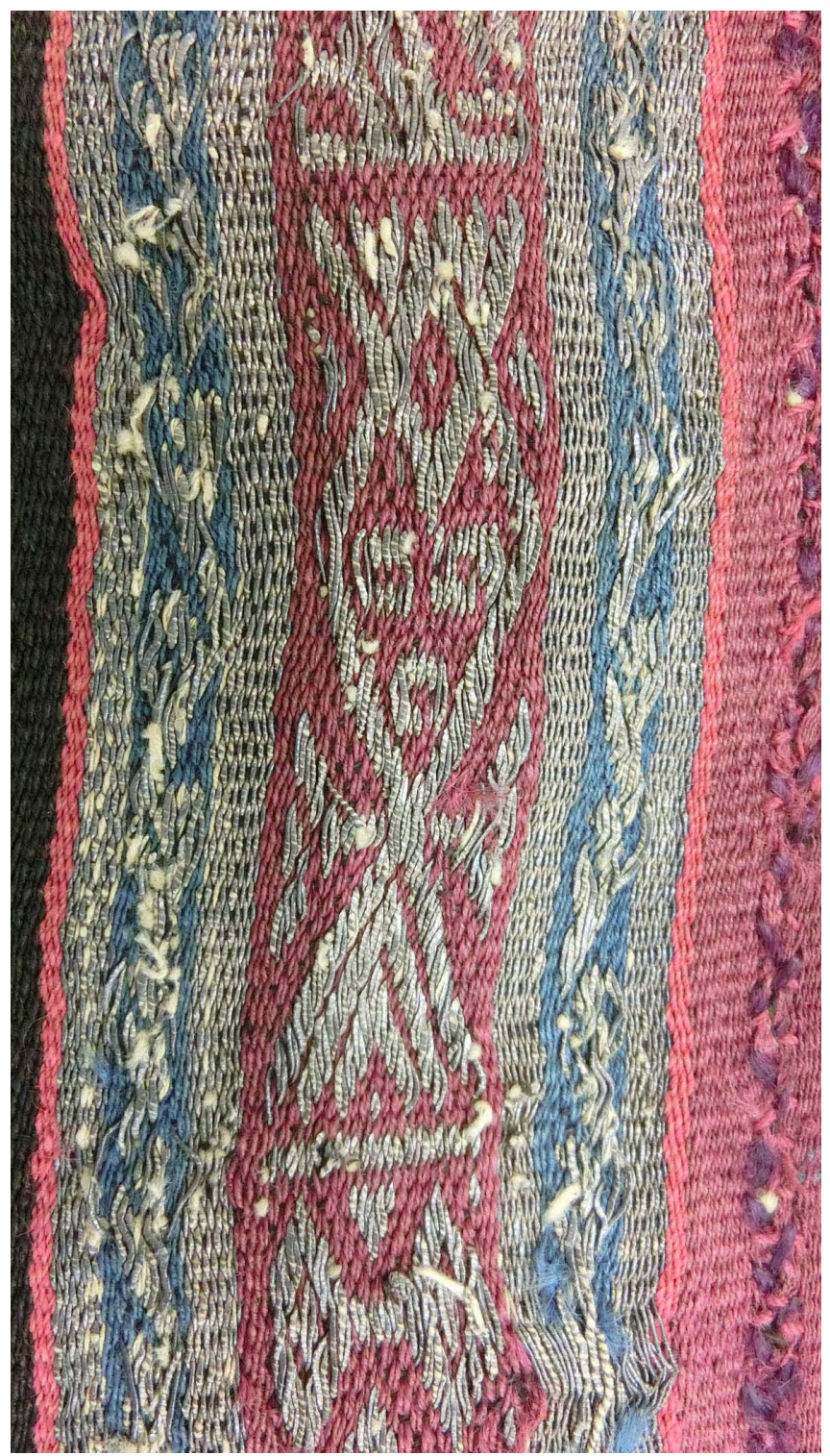

Figure 12. Enlarged detail of a decorated stripe (DTM Inv. Nr. 12219)

stripes, which is called pallay in Quechua. Which part was replaced with the silver thread? A close-up of the silver threads shows that they were used as pattern warps in the traditional way. The lliclla presented here is made from two four-selvedged cloths, with different widths: 36 and $41 \mathrm{~cm}$ wide. The motives in the stripes are both figurative and geometric (Fig. 12). Only the ends of the pallay-stripe carry recognizable anthropomorphic motives. ${ }^{32}$

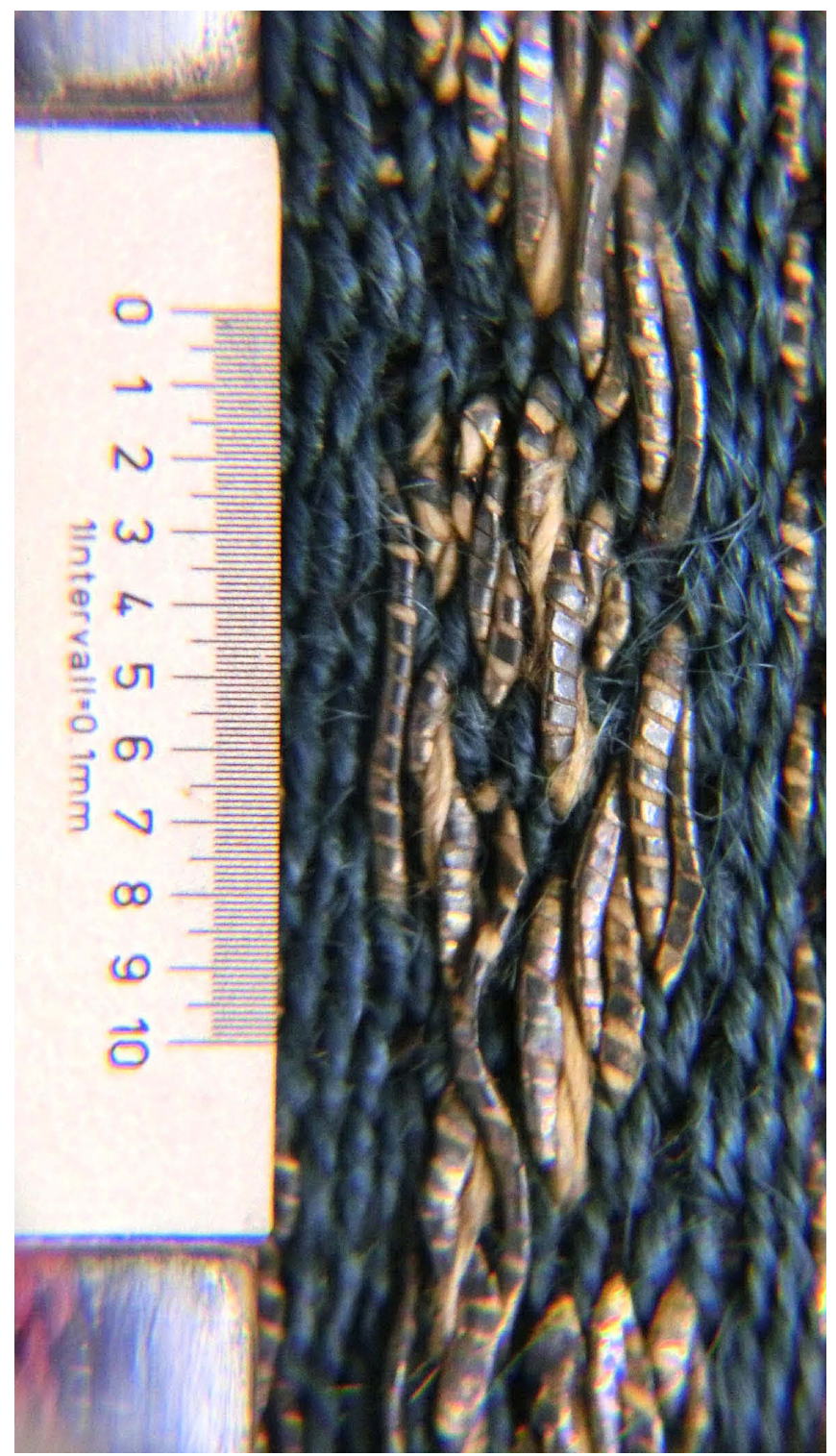

Figure 13. Enlarged photo of the silver threads. Two details of the decorated silver stripes of the two llicllas (DTM Inv. Nr. 12219 and DTM Inv. Nr. 11286)

This thread is made with solid, flat metallic strips cut from sheets of pure silver wound around the core yarn. The core material is silk. Elena Phipps describes different kinds of metal yarns. ${ }^{33}$ Depending on the amount of the metal, the core was covered completely or left with visible areas. In this example, the core is almost covered. This is obviously a highly valuable thread (Fig. 13).

Metal yarn is less flexible than camelid hair or woollen

32. To interpret this motive it is worth to look at the „ch' unchu“ motive of some llicllas of the Q'ero as symbol of the „inkarrí”. See: G. Silverman, 1994, 84, fig. 3.15 and 149, fig. 7.1 The word inkarrí is a composition of the Quichua word Inka and the Spanish rey, king. In the Andean collective memory this this mythical figure appears as a fusion of the last Incas killed by the conquerors. This historical moment was after the rebellion with the Andean leader Túpac Amaru II. was struck down in 1780. López-Baralt, 2011, 227.

33. E. Phipps, 2010, 7-9 


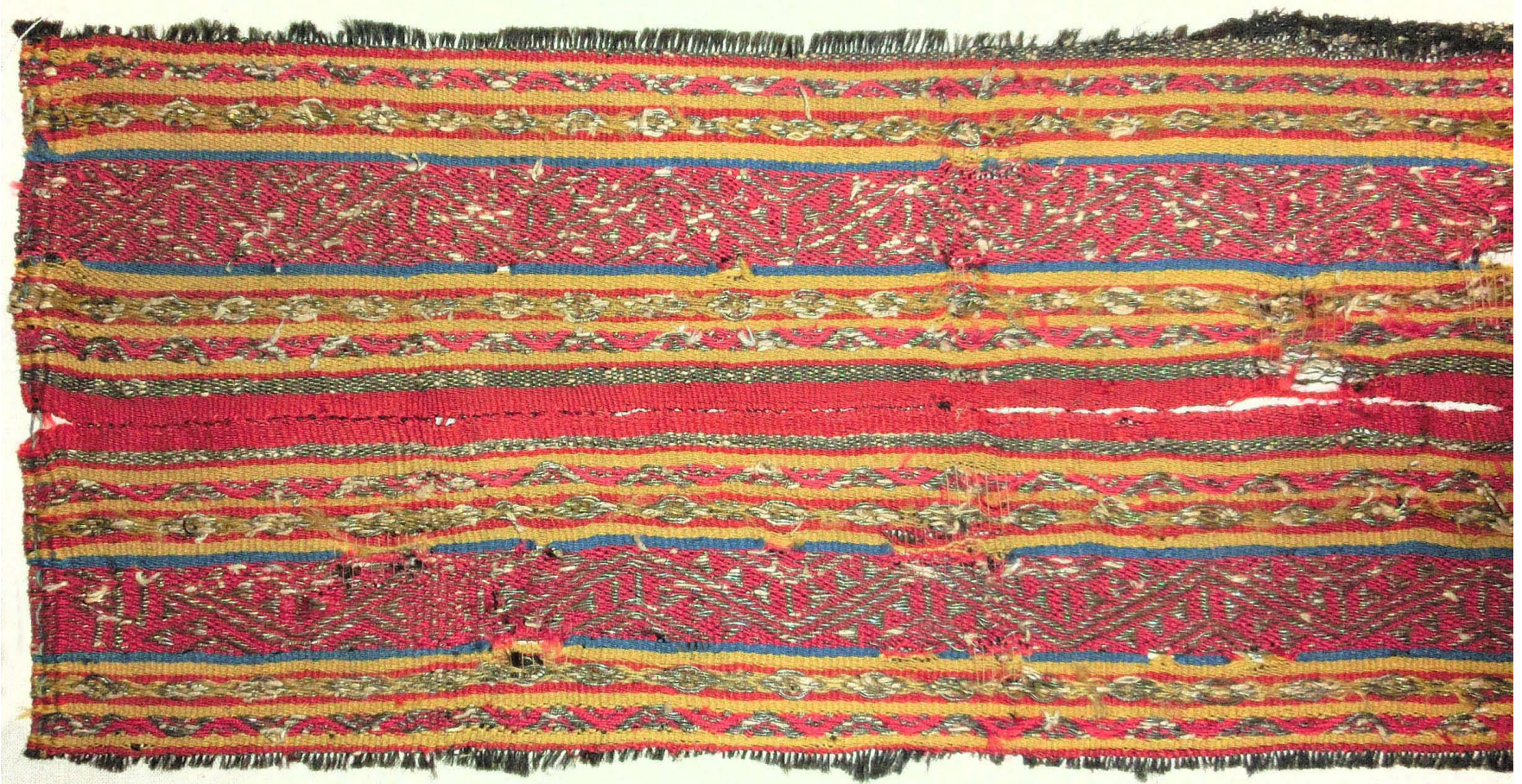

Figure 14. Decorated middle part of a women`s shawl, lliclla, fragment, probably $18^{\text {th }}$ Century. Camelid hair, natural and dyed, with silver threads, 93 x 16,5 cm (DTM Inv. Nr. 11286)

Figure 15. Enlarged photo shoot of the silver threads of the lliclla fragment (DTM Inv. Nr. 11286)

yarns, therefore, it is well suited for the warp pattern stripe with a constant direction. But metal threads were also used for weft, mainly in tapestries or for embroidery.

“Men's Inca-style garments, which continued to be worn by elite Andeans in the colonial era, often incorporated some metallic yarns." ${ }^{34}$ In tapestry they were used as weft elements for small scale designs, such as small animals, or faces of the sun. This kind of tapestry weaving was typical for the Inca-style garments, but during the pre-Columbian era metal yarns were never used. ${ }^{35}$

Another piece is presented here for comparison. It is a fragment of a similar lliclla and measures 93 by $16,5 \mathrm{~cm}$ (Fig. 14). The quality of this silver yarn is similar to the previous one but it is in a better condition (Fig. 15).

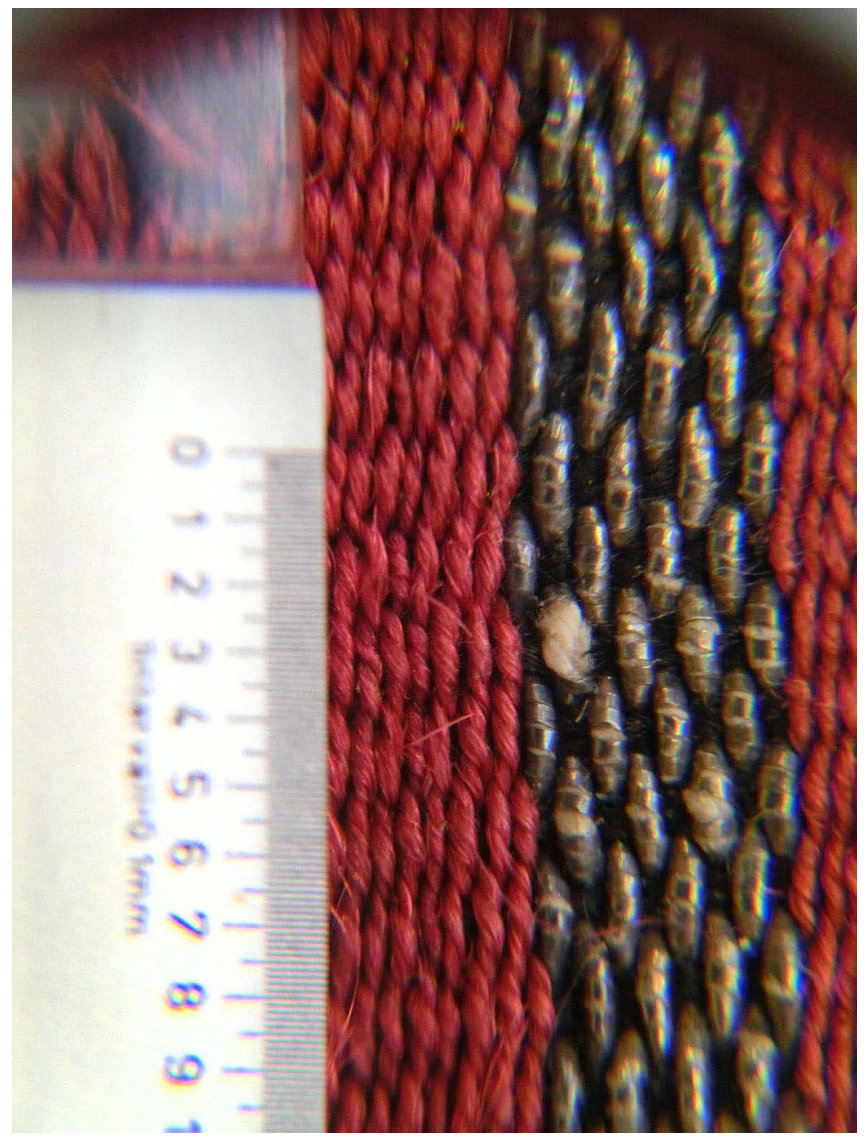




\section{Summary}

The facts above support the statement that the collection was not created because of a scientific interest in archaeological, historical, or cultural questions but rather due to the interest in the technical and technological possibilities to produce different textile objects and garments. The one and only reason to gather the items was to create a collection of textile techniques, which is, in fact, a collection of textile pieces. The school was created by the wealthy factory owners of Krefeld, a city, which at that time, had already had a very long textile tradition. Thus, the acquisition of such a collection and the modernisation of the education in the Weaving School (Crefelder Höhere Webschule) significantly added to the image of the city. ${ }^{36}$ With it, the city expressed its awareness of its history and pride in the source of its prosperity - textile manufacturing.

Today the museum is a place for scholars from all over the world to meet. The museum has several expositions of modern textile art, it also has a good library with special conditions for studying the history of textile culture in general and the history of pre-Columbian textiles.

\section{Acknowledgments}

The investigation on the pre-Columbian collection of the German Textile Museum is part of the current project "Shed light", funded by the cultural fund of the Sparkasse Krefeld. My cordial thanks to Annette Paetz gen. Schieck, the director of the German Textile Museum in Krefeld. Also, I would like to express my great gratitude to the team of the Museum in Krefeld. Their heartful welcome and comprehensive assistance helped me considerably in getting ahead. Also, many thanks to Lena Bjerregaard and Ann $\mathrm{H}$. Peters, their comments and questions helped me to make the text more clear.

\section{References}

Arnold, Denise Y. and Penelope Dransart (ed.)

2014, Textiles, Technical Practice, and Power in the Andes. Archetype Publications Ltd. London

Bergh, Susan E.

2012, Wari: Lords of the Ancient Andes. Cleveland Museum of Art, Cleveland. Thames \& Hudson, New York

British Museum, database

2019, https://research.britishmuseum.org/research/ search_the_collection_database/term_details. aspx?bioid $=35776$ (source 26.11 .2019 )
Campos, Jose Alfredo

2015, Conservación y restauración de bienes culturales en el MUSEF. In: Jaimes Betancourt, 2015:479-486)

Fischer, Manuela

1992, Amerika aus der Sicht des Sammlers: Die Sammlungen südamerikanischer Archäologica des Museums für Völkerkunde, Berlin. In: Amerika 1492 - 1992. Neue Welten - Neue Wirklichkeiten. Essays. (257-263). Ibero-Amerikanisches Institut Preußischer Kulturbesitz und Museum für Völkerkunde Staatliche Museen zu Berlin. Westermann, Braunschweig

\section{Gewebesammlung Krefeld}

1971, Kostüme, Trachten, Schmuck aus aller Herren Länder. Catalogue with an introduction by Renate Jaques. Gewebesammlung Krefeld, Krefeld

Heiden, Max,

1904, Handwörterbuch der Textilkunde aller Zeiten und Völker für Studierende, Fabrikanten, Kaufleute, Sammler und Zeichner der Gewebe, Stickereien, Spitzen, Teppiche und dergl., sowie für Schule und Haus. Verlag F. Enke, Stuttgart

Jaques, Renate,

1969, Jourtextilien aus dem Chancaytal in der Sammlung Amano in Lima. In: Verhandlungen XXXVIII. Internationalen Amerikanistenkongresses, Stuttgart - München, 12. bis 18. August 1968, Band I. Komissionsverlag Klaus Renner, München

Jaimes Betancourt, Carla,

2015, El poder de las plumas. Museo Nacional de Etnografía y Folklore, La Paz. La Paz, Bolivia

King, Heidi,

2012, Peruvian Featherworks. The Metropolitan Museum of Art, New York

López-Baralt, Mercedes,

2011, El Inca Garcilaso, traductor de culturas. Iberoamericana, Vervuert, Frankfurt am Main

Paetz gen. Schieck, Annette,

2013, Transformation Processes of the Jakob Krauth Textiles Collection into a Study Collection and Emergence of the Deutsches Textilmuseum Krefeld, Germany. In: Belleza Rosina, Margherita (ed.): Collecting Textiles. Patrons Collections Museum. 2013: 47-62. By Fondazione Ratti. Allemandi \& C., Torino

Peters, Ann H.,

2014, Paracas Necropolis: communities of textile production, exchange networks, and social 
boundaries in the Central Andes, $150 \mathrm{BC}$ to $\mathrm{AD} 250$.

In: Arnold and Dransart, 2014: $109-139$

Phipps, Elena,

2010, Woven Silver and Gold: Metallic Yarns in Colonial Andean Textiles. In: Source: Notes in the History of Art. Vol. 29, No. 3, Special Issue: Paradoxes and Parallels in the new World (Spring 2010: 4-11) The University of Chicago Press, Chicago

Reiss, Wilhelm und Alphons Stübel,

1880 - 1887, The Necropolis of Ancon in Peru. Published by A. Asher, Berlin
Rowe, Ann Pollard,

2012, Tie-dyed Tunics. In: Bergh, S. E., 2012: 193-206.

Silverman, Gail,

1994, El tejido andino: un libro de Sabiduría. Banco Central de Reserva del Perú, Lima

Stanfield-Mazzi, Maya,

2015, Weaving and Tailoring the Andean Church: Textile Ornaments and their Makers in Colonial Peru. In: The Americas. A Quarterly Review of Latin American History, Vol. 72, special issue 01. pp 77-102. Cambridge University Press, Cambridge 